\begin{tabular}{ll}
\hline Jurnal Scripta Teologi dan Pelayanan & \\
ISSN 2086-5368 (Print) & STT Ebenhaezer \\
ISSN 2722-8231 (Online) & STTE \\
Http://ejournal.stte.ac.id & \\
Vol.9, No.1, pp. 91-105, 2020 & \\
\hline
\end{tabular}

\title{
Hubungan Covid 19 Dengan Wahyu 6:8
}

\author{
Rustam Siagian \\ Dosen di STTE, siagian.rustam@gmail.com
}

\section{INFO ARTIKEL}

Sejarah Artikel:

Diterima : 20 Sep 2020

Direvisi : 05 Okt 2020

Disetujui: 20 Okt 2020

Dipublikasi: $22 \mathrm{Okt}$

2020

Kata-kata Kunci:

Hubungan, Covid 19,

Wahyu 6: 8

Keywords:

Covid 19, Revelation, Prophecy

\begin{abstract}
ABSTRAK
Covid 19 telah menular kepada hampir semua negara di dunia. Sejauh ini angka kematian yang diakibatkan oleh covid 19 ini di seluruh dunia telah mencapai angka 340.383 orang. Nampaknya angka ini akan terus bertambah, mengingat penyebaran virus ini begitu cepat, menjalar seperti api. Dalam tulisan ini akan dianalisa apakah ada hubungan antara nubuatan dalam Wahyu 6:8 dengan covid 19 ini.

Untuk mencapai tujuan itu, penulis menggunakan pendekatan kualitatif dengan metoda eksegesis terhadap teks Wahyu 6:8. Dari penelitian yang dilakukan bahwa sejauh ini jumlah kematian yang diakibatkan covid 19 masih jauh lebih kecil dibandingkan dengan jumlah kematian yang dinubuatkan dalam Wahyu 6:8. Bahwa dalam Wahyu 6:8, jumlah kematian yang diakibatkan malapetaka yang akan menimpa manusia seperempat penduduk bumi. Jika sekarang penduduk dunia sebanyak 7,8 miliar, berarti seperempatnya adalah 1.9 milliar. Dengan demikian nubuatan dalam Wahyu 6:8 tidak menunjuk kepada covid 19. Tetapi jika angka yang diakibatkan oleh covid 19 terus meningkat dan penemuan vaksin masih beberapa tahun ke depan, sehingga kematian manusia akibat covid 19 ini mencapai seperempat penduduk bumi, maka bisa saja covid 19 bisa merujuk kepada nubuatan dalam Wahyu 6:8.
\end{abstract}

\section{ABSTRACT}

Covid 19 has spread to almost all countries in the world. So far the death rate caused by covid 19 worldwide has reached 340,383 people. It seems that this number will continue to grow, considering the spread of this virus is so fast, spreading like wildfire. In this paper, we will analyze whether there is a relationship between the prophecies in Revelation 6: 8 and Covid 19.

To achieve this goal, the author uses a qualitative approach with an exegetical method to the text of Revelation 6: 8. From the 
research conducted, so far the number of deaths caused by Covid 19 is still much smaller than the number of deaths prophesied in Revelation 6: 8. That in Revelation 6: 8, the number of deaths resulting from calamities that will befall humans a quarter of the population of the earth. If now the world's population is 7.8 billion, that means a quarter is 1.9 billion. Thus the prophecy in Revelation 6: 8 does not refer to covid 19. But if the numbers caused by covid 19 continue to increase and vaccine discoveries are still a few years from now, so that human deaths due to covid 19 will reach a quarter of the earth's population, then it could be covid 19 can refer to the prophecy in Revelation 6: 8.

Pendahuluan

Covid-19 merupakan wabah dengan tingkat penularan yang begitu cepat menjangkiti umat manusia di abad ini. Hanya dalam hitungan bulan saja, virus ini telah menjangkau hampir semua negara di seluruh penjuru dunia ini. Virus ini pertama sekali muncul pada bulan November 2019 di kota Wuhan China. Ditengarai bahwa virus ini menular melalui kontak manusia dengan hewan di 
salah satu pasar makanan di kota Wuhan. Kemudian virus ini menyebar dengan mudahnya dari orang per-orang melalui kontak fisik, tetesan cairan melalui batuk atau bersin.

Dalam beberapa bulan saja, Covid-19 telah menyebar seperti api ke hampir seluruh penjuru dunia. Data pada tanggal 7 Mei 2002 bahwa Covid-19 ini terkonfirmasi telah menginfeksi 3.870.865 orang, dengan jumlah kematian

sebanyak 267.771 orang. ${ }^{1}$

Berbagai upaya dilakukan oleh berbagai bangsa untuk menghadapi virus corona ini. Salah satu upaya yang serius diterapkan di beberapa negara adalah dengan kebijakan lockdown, yaitu dengan menutup akses keluar masuk ke suatu kota atau area tertentu. Tujuannya untuk mengurangi kontak antar personal, dengan harapan penyebaran virus corona dapat dihentikan.

Beberapa negara berhasil menekan tingkat penularan virus ini, tetapi ada juga beberapa negara yang kewalahan, sehingga jumlah masyarakat yang terinfeksi virus ini terus bertambah, bahkan angka kematian pun makin bertambah juga. Karena itu jika memperhatikan laporan dari berbagai media cetak dan elektronik, jumlah orang yang terinfeksi akan cenderung terus bertambah. Sedangkan di Indonesia, kebijakan pemerintah untuk menekan laju pertambahan jumlah orang yang terinfeksi virus corona ini adalah dengan menerapkan PSBB (Pembatasan Sosial Berskala Besar). Beberapa saat program ini berhasil mengurangi jumlah orang yang terinfeksi, tetapi kemudian menjadi masalah ketika pemerintah menerapkan kebijakan baru yaitu pola normal baru.

Pada kenyataannya, kebijakan baru ini telah menimbulkan masalah baru dalam masyarakat. Karena begitu kebijakan normal baru ini diterapkan justru jumlah orang yang terinfeksi makin meningkat, bahkan pertambahannya begitu signifikan. Karena itu keadaan sekarang ini malah makin tidak terkendali bahwa jumlah orang yang terpapar virus corona ini terus bertambah-tambah. Nampaknya wabah ini masih akan terus menjangkiti banyak orang dalam waktu yang belum bisa diprediksi. Karena itu wabah corona ini menimbulkan beberapa pertanyaan yang patut menjadi perhatian.

Apakah pandemik corona ini mempunyai hubungan dengan wabah yang dinyatakan oleh wahyu 6:8?

\section{Metoda}

Penulisan ini menggunakan pendekatan penelitian kualitatif dengan metode eksegesis. Pertama, memberi perhatian kepada teks Wahyu 6:8, sebagai sudut pandang untuk memberi penilaian terhadap covid 19. Tentu akan dilakukan analisa konteks, gramatikal dan kata dari teks Wahyu 6:8. Kedua, memberi perhatian kepada pembahasan mengenail covid 19, sebagai wabah yang menggemparkan dunia sekarang ini. Pembahasan tentang covid 19 berkenaan dengan ciri dan penyebaran serta jumlah kematian oleh virus ini. Tujuan penjelasan tentang covid 19 ini tentu bukan untuk melihat secara detail tentang apa dan bagaimana adanya virus ini, melainkan hanya untuk melihat seberapa banyak jumlah orang yang tertular dan tingkat kematian yang terjadi oleh virus ini.

\footnotetext{
${ }^{1}$ https://samoaglobalnews.com/does-covid-19-fulfill-biblical-plague-prophecies, 18 Mei 2020
} 
Kemudian mengamati hubungan nubuatan dalam Wahyu 6:8 yang menjelaskan tentang adanya suatu wabah yang mematikan pada suatu masa terjadi dalam sejarah manusia dengan covid 19. Apakah wabah yang dimaksudkan dalam Wahyu 6:8 sama dengan wabah virus corona ? Kalau tidak sama, berarti keduanya tidak memiliki hubungan, bahwa apa yang dinubuatkan dalam Wahyu 6:8 tidak menunjuk kepada wabah covid 19. Tetapi kalau sama berarti keduanya memilki hubungan, bahwa nubuatan dalam Wahyu 6:8 menunjuk kepada covid 19.

\section{Pembahasan \\ Konteks teks}

Untuk mengerti suatu teks, sangat penting untuk memahami konteks teks itu agar menemukan makna yang tepat dari teks tersebut. Memahami teks wahyu 6:8 dalam konteksnya maka hal itu dimulia dari penglihatan Rasul Yohanes tentang Yesus Kristus yang dimuliakan dalam Wahyu 1. Kemudian Yesus Kristus mengarakan Yohanes untuk menuliskan pesan-pesan yang ditujukan terhadap ke tujuh gereja dalam pasal 2-3. Sesudah itu penglihatan diarahkan kepada ruang takhta yang tertulis dalam Wahyu 4-5 untuk mempersiapkan jalan bagi penghakiman Allah yang adil. yang dimulai pada pasal 6.

Hanya Yesus Kristus yang layak (5: 2-5) dari semua makluk di alam semesta ini untuk membuka gulungan kitab itu. Dan kemudian mulai membuka gulungan kitab dengan membuka meterainya. Hal ini memulai tiga pola bentuk penghakiman dalam Wahyu 6-16 yaitu meterai, sangkakala, dan cawan, dengan masing-masing menggunakan pola empat-tiga.

Wahyu pasal 6 dapat dibagi menjadi tiga bagian. Empat meterai pertama membentuk unit yang menampilkan sosok simbolik dari empat kuda berwarna. Bagian kedua menggambarkan jiwa-jiwa di bawah altar dan mewakili orang-orang yang mati karena iman mereka kepada Tuhan. Dan bagian terakhir menggambarkan penghakiman dan teror mereka yang menolak Kristus.

Anak Domba membuka meterai satu demi satu, sehingga peristiwa-peristiwa yang digambarkan secara gamblang dalam gulungan dapat terpenuhi. Dengan membuka meterai dan gulungan itu, Anak Domba menyatakan rencana Allah dan mengungkapkan apa yang harus terjadi pada zaman sebelum dan pada kedatangan-Nya. Dengan membuka meterai satu per satu, hal itu menunjukkan bahwa Anak Domba yang berotoritas atas berbagai peristiwa-peristiwa yang terjadi dalam pasal ini.

Hanya Anak Domba, yang layak untuk membuka meterai, telah mengambil gulungan itu. Ketika meterai dibuka, mereka secara progresif mengekspos dan menyatakan rencana akhir Allah untuk menyingkirkan dunia kejahatan. Namun ini adalah langkah awal, karena gulungan itu tidak akan sepenuhnya terbuka sampai ketujuh meterai telah dibuka. Ketika Anak Domba membuka masing-masing dari empat meterai pertama, salah satu dari empat makhluk hidup dari 4: 6-8 memanggil keluar "empat penunggang kuda," yang menunjukkan bahwa setiap bagian dari peristiwa ini datang atas perintah dari tahta Allah. Tema dari bagian ini adalah kebobrokan absolut umat manusia. 
Setiap penunggang kuda menunjukkan bahwa umat manusia semakin dalam dan semakin dalam ke dalam dosa, dan bersama-sama mereka menunjukkan sifat dosa yang merusak diri sendiri. Namun tiga kali dalam bagian ini Tuhan memberikan otoritas kepada para penunggang $(6: 2,4,8)$, menunjukkan kuasa mutlak Tuhan atas seluruh proses. Bahkan kekuatan kejahatan hanya bertindak atas izin ilahi.

Unsur waktu tentang munculnya kuda keempat dapat dipahami sebagai peristiwa yang terjadi secara berurutan atau bersamaan. Ada orang yang lebih menyukai yang kedua dari pada yang pertama. Dengan pehaman itu bahwa, penaklukan, peperangan, kelaparan, dan wabah penyakit adalah peristiwa yang terjadi secara bersamaan pada zaman atau pada era tertentu. $^{2}$

Dalam sejarah dunia, yang penuh dengan kekerasan dalam bentuk yang beragam, menunjukkan gereja sebagai milik Tuhan berada pada posisi sentral, dan umat Tuhan secara berulang mengalami penderitaan dan ketidakadilan karena kesaksian mereka tentang Anak Domba. Hal itu ditunjukkan dengan dibukanya meterai demi meterai oleh Anak Domba.

Pembukaan meterai menyiratkan bahwa orang-orang kudus di bumi menderita dari mereka yang melawan Anak Domba, hingga sampai hari kembalinya Kristus kedua kali. Tidak heran jika para martir di surga berseru kepada Tuhan untuk meminta keadilan. Tetapi mereka diminta untuk bersabar dan memahami bahwa Tuhan yang berdaulat mengontrol sejarah dunia. Bahwa murka-Nya akan ditujukan kepada mereka yang terus menunjukkan sikap bermusuhan kepada Tuhan dan kepada umat-Nya. Ketika Anak Domba membuka meterai satu demi satu, maka peristiwa-peristiwa yang digambarkan dalam gulungan itu akan digenapi. Dengan membuka meterai dan membuka gulungan itu, Anak Domba menyatakan bahwa rencana Tuhan harus terjadi pada waktu sebelum dan saat kedatanganNya, yang kedua. Dengan membuka meterai satu per satu oleh Anak Domba, memperlihatkan bahwa yang menjadi pemrakarsa setiap peristiwa dalam pasal 6 ini adalah

Tuhan sendiri.

\section{Penafsiran terhadap wahyu 6:8}

Dalam bagian ini ditunjukkan bahwa Yohanes melihat kuda yang keempat dan yang mengedarainya serta dampak kerusakan yang dilakukan penunggang kuda yang keempat ini.

Teks Wahyu 6:8 ini diawali dengan kalimat KaI eIdon KaI Idou menunjukkan bahwa ayat ini merupakan lanjutan dari ayat sebelumnya, kata eIdon kata kerja aorist indikatif aktif orang pertama tunggal artinya melihat, dari tensenya diterjemahkan menjadi aku telah melihat dan lihatlah (Idou). ${ }^{3}$ Suatu penegasan bahwa Yohanes sungguh melihat apa yang ditunjukkan Tuhan kepadanya, sehingga penyataan Yohanes bukan suatu khayalan atau rekaan belaka. Apa yang dilihat Yohanes adalah fakta tentang penglihatan yang ditunjukkan Tuhan padanya, sehingga apa yang dilihat Yohanes adalah nyata sebagaimana yang Tuhan perlihatkan kepadanya. Berbagai peristiwa yang akan datang sedang Tuhan tunjukkan kepada Yohanes untuk disampaikan

\footnotetext{
${ }^{2}$ Simon J., Kistemaker.; William, Hendriksen, William: New Testament Commentary: Exposition of the Book of Revelation. Grand Rapids: Baker Book House, 2001, 218

${ }^{3}$ BibleWork 7, Wahyu 6:8
} 
kepada jemaat agar mereka memahami bahwa Tuhan yang berkuasa dan terus berkuasa atas sejarah manusia. Karena itu jemaat yang sedang mengalami penganyiayaan tidak perlu berkecil hati sebab sesungguhnya Tuhan adalah pengendali semua peristiwa itu.

Hal yang dilihat Yohanes adalah Ippoj clwroj , kedua kata ini dalam bentuk nominatif tunggal, dan nampaknya kata benda Ippoj sebagai nominatif independen. Pengertian dari nominatif independen adalah kata benda yang berada dalam kasus nominatif yang tidak memiliki hubungan sintaktikal dengan suatu kalimat yang ada. Biasanya nominatif jenis ini muncul dalam kalimat salam, judul surat. Ketika nominatif ini dituliskan umumnya selalu disertai dengan kata tambahan untuk menjelaskan nominatif tersebut. ${ }^{4}$ Kata Ippoj sebagai kata benda nominatif tunggal dalam hubungan dengan clwroj adalah sebagai kata sifat. Dengan memperhatikan pola hubungan kedua kata ini, maka kata sifat clwroj berfungsi sebagai kata sifat attributif, sehingga rangkaian kedua kata berarti kuda yang pucat. Kata pucat sebenarnya berwarna hijau kekuningan, atau warna mayat. Dalam bahasa Yunani warna kekuning-kuningan ini, digunakan untuk menunjukkan warna mayat. ${ }^{5}$ Pada bagian lain, seekor kuda pucat merupakan gambaran orang Yahudi untuk malaikat maut atau penampilan orang mati. Karena pucat adalah warna kematian dan pembusukan, seperti daun atau orang mati. ${ }^{6}$

Berarti kuda berwarna hijau kekuningan ini hendak menyatakan akan adanya kematian yang melanda umat manusia. Memang kematian telah menjadi bagian yang tak terpisahkan dari hidup manusia sejak Adam melakukan dosa. Namun kematian yang diisyaratkan dalam ayat ini merupakan kematian yang khusus karena penyebabnya yang tidak biasa dan jumlah kematian yang melampaui dari yang normal, nats ini menunjukkannya secara spesifik.

Kemudian kata Kaqhmenoj merupakan kata kerja partisif present middle nominatif maskulin tunggal, sehingga diterjemahkan menjadi sementara dia yang duduk diatasnya. Kedua kata onoma autw Î sehingga dapat diterjemahkan namanya kematian atau maut. Klausa yang menyusul adalah KaI o adhj hKolouqe I met/ autou , kata hKolouqe adalah kata kerja imperfek indicatif aktif orang ketiga tunggal, sehingga diterjemahkan hades telah sedang mengikut bersama dia. ${ }^{7}$

Dengan demikian kematian atau maut yang duduk di atas kuda itu, dan hades menyertainya. Dari penjelasan ini nampaknya hades mengikutinya bukan dengan kuda karena dalam bagian ini tidak disebutkan ada kuda kelima, sehingga hades mengikutinya dengan berjalan kaki. ${ }^{8}$ Pengertian hades dalam bagian ini bukanlah menunjuk kepada kuburan atau tempat di mana jiwa orang-orang mati disimpan. Bahwa Maut dan Hades yang mengikutinya, keduanya dipersonifikasikan sebagai kekuatan kosmik ganas dalam kitab Wahyu ( Wah 1:18; 6: 8; 20:13, 14). ${ }^{9}$ Pendapat lain mengatakan bahwa maut

\footnotetext{
${ }^{4}$ Welly Pandensolang, Gramatika dan Sintaksis Bahasa Yunani Perjanjian Baru; Jakarta, YAI Press, 2010, hal 128

${ }^{5}$ Grant R. Oborne. Revelation, Verse by Verse Osborne New Testament Commentaries, Bellingham, Lexham

Press, 2016, hal 107

${ }^{6}$ http://www.intothyword.org/apps/articles/web/articleid/33364/columnid/3803/default.asp, 11 Mei 2020

${ }^{7}$ BibleWork.. Wahyu 6:8

${ }^{8}$ Robert L. Thomas. Revelation, An Exegetical Commentary, Chicago; Moody Press, 1995, hal 437

${ }^{9}$ Ibid, hal
} 
dan hades merujuk kepada penggambaran kematian. ${ }^{10}$ Dengan demikian maut dan hades ini bukan sedang menunjukkan tentang keadaan penghukuman di neraka melainkan sebagai perlambangan dari tokoh kegelapan, yang mendatangkan bencana besar bagi manusia. Skala bencana yang dialami manusia dengan ke hadiran maut dan hades ditegaskan dalam kalimat selanjutnya. Bahwa malapetaka yang dihadirkan oleh maut dan hades sangat menggemparkan karena jumlah kematian yang terjadi sangat besar dengan pola tertentu.

Kalimat selanjutnya KaI edoqh autoIj exousIa epI to tetarton thj ghj apoKteInaI Kata edoqh kata kerja aorist indikatif pasif orang ketiga tunggal dengan exousIa sebagai nominatif, sehingga bagian ini dipahami sebagai "kuasa telah diberikan kepada mereka sekitar seperempat bumi untuk dibunuh"

Kalimat yang ditulisakan dalam bagian ini dalam bentuk pasif. Hal itu menegaskan bahwa maut dan hades dapat menjalankan aksinya bukan atas kehendaknya sendiri tetapi atas seizin yang memberi kuasa, kesempatan kepada mereka.

Kalau kepada mereka tidak diberi kesempatan maka mereka tidak akan dapat berbuat sesuatu. Artinya bahwa yang mengendalikan sejarah, segala kuasa atas dunia ini, termasuk kuasa maut dan hades, bukan Iblis tetapi Dia yang berkuasa membuka meteraimeterai Allah. Hanya Dia saja yang memiliki kuasa atas sejarah dan alam semesta ini.

Kuasa yang diberikan kepada mereka adalah untuk membunuh seperempat dari bumi. Kata membunuh dituliskan dalam bentuk infinitif aorist. Dalam bahasa Yunani bentuk infinitif lebih menunjuk kepada aspek, atau jenis tindakan, bukan pada waktu tindakan. Infinitif present mewakili tindakan yang sedang berlangsung, sementara Infinitif Aorist menunjukkan kepada tindakan lengkap yang hanya mengatakan sesuatu terjadi tanpa menunjukkan kapan. ${ }^{11}$ Artinya tindakan pembunuhan yang dilakukan oleh maut dan hades tidak diberitahukan secara detail kapan dan berapa lama. Tetapi yang pasti bahwa malapetaka kematian yang akan dialami manusia oleh perbuatan maut dan hades dalam jumlah yang sangat besar. Karena mereka akan membunuh seperempat dari penduduk bumi. Jika sekarang penduduk dunia berada pada kisaran 7,8 miliar, berarti seperempat dari angka itu adalah 1,9 miliar. Suatu angka kematian yang sangat fantastis, suatu angka kematian manusia yang belum pernah terjadi dalam sejarah manusia. Bagian terakhir dari ayat ini en romfaIa KaI en 1 Imw KaI en qanatw KaI upo tw

qhrIw $n$ thj ghj untaian frasa ini menggunakan kontruksi peroposisi en diikut

oleh tiga kata benda dalam kasus datif, hanya kata benda terakhir yang menggunakan preposisi upo. Nampaknya, pola ini menyatakan proposisi sarana, bahwa kekuatan jahat ini akan menggunakan sarana yang dipakai untuk membunuh adalah melalui pedang, kelaparan, kematian dan oleh binatang buas bumi. Rangkaian pembunuhan manusia dengan dengan pedang dan dengan kelaparan dan dengan kematian dan oleh binatang buas di bumi, digunakan dengan cara yang sama dalam PL. ${ }^{12}$ Berarti pola kematian yang terjadi oleh maut dan hades ini merupakan cara yang umum, hanya skala kematian yang diakibatkan menurut nats ini jauh melampaui yang biasa. Dalam nats ini secara khusus kata qanatos mengandung arti kematian.

Beberapa penafsir menyatakan bahwa kata itu juga mengandung arti wabah atau penyakit. Penggunaan kata qanatos dalam ayat $8 \mathrm{~b}$ merujuk pada tulah, penyakit dari pada kematian dalam pengertian umum. Bahwa faktanya

penggunaan kata qanatos dalam LXX merupakan penerjemahan dari bahasa 
Ibrani deber artinya tulah, wabah digunakan lebih dari tiga puluh kali. ${ }^{13}$ Hal yang sama disampaikan oleh J. Scott Duval bahwa kata qanatos diterjemahkan dengan wabah, penyakit. ${ }^{14}$ Pendapat selanjutnya mengataan bahwa kata qanatos secara umum diterjemahkan kematian dan dalam Septuaginta

diterjemahkan deber. Namun kata qanatos ini dapat mengandung konotasi sebagai sampar, atau wabah. ${ }^{15}$

Kata qanatos dalam pengertian sampar, wabah digunakan tiga kali dalam kitab Wahyu. Dalam Wahyu 2:23, ini digunakan dalam konteks peristiwa khusus yang terjadi di masa lalu. Referensi kedua ditemukan dalam Wahyu 6:

8. Penunggang kuda pucat diberi wewenang atas seperempat bagian bumi, untuk memukul dengan pedang, kelaparan, dan penyakit sampar. Seperti Matius 24 dan Lukas 21, penyakit sampar diperkirakan menjadi karakteristik umum sejarah yang bisa membunuh manusia dalam jumlah yang tinggi.

Referensi ketiga untuk qanatos yang diterjemahkan sebagai kematian atau sampar ditunjukkan dalam konteks akhir zaman dalam Wahyu 18:8. Sampar

adalah salah satu konsekuensi dari kejatuhan Babel, tepat terjadi sebelum kedatangan Yesus yang kedua kali. Karena itu sampar atau wabah sebagai pembunuh dalam sejarah manusia telah menjadi isu yang penting untuk diperhatikan. Dari penjelasan sebelumnya dapat dikatakan bahwa terjemahan yang lebih tepat untuk kata qanatos adalah sampar atau wabah. Karena kalau qanatos diterjemahkan dengan kematian maka pengertiannya menjadi tidak sejalan dengan kata yang dipakai secara berurutan dalam Wahyu 6:8 pada kalimat terakhir. Bahwa dalam bagian terakhir dari Wahyu 6:8 itu dituliskan dan kepada mereka diberi kuasa atas seperempat dari bumi untuk membunuh dengan pedang dan dengan kelaparan dan dengan kematian ${ }^{16}$ (qanatos). Dengan menggunakan kata kematian dalam bagian itu akan menunjukkan bahwa kalimat menjadi membingungkan karena antara sarana digunakan untuk tujuan kematian, seperti pedang serta kelaparan disejajarkan dengan tujuan penggunaan sarana-sarana itu yaitu kematian. Karena itu kata qanatos lebih baik diterjemahkan dengan sampar atau wabah.

Dengan demikian menjadi jelas sarana yang dipakai oleh maut dan hades menurut Wahyu 6:8 untuk membunuh manusia yaitu dengan pedang, kelaparan, wabah dan binatang buas. Sarana itu begitu efektif sehingga jumlah kematian yang diakibatkannya sangat luar biasa banyak sampai

${ }^{13}$ G. K. Beale. The Book of Revelation : A Commentary on the Greek Text. Grand Rapids, Mich.; Carlisle, Cumbria : W.B. Eerdmans; Paternoster Press, 1999, 382

${ }^{14}$ J. Scott Duval, Revelation, Teach The Tex t, Commentary Series, Grand Rapid Michigan, Baker Publishing Group, 2014, 190

${ }^{15}$ https://signsofthetimes.org.au/2020/04/does-the-bible-predict-covid-19, Mei 2020

${ }^{16}$ Alkitab (TB), Wahyu 6:8b. LAI, 2012 
mencapai jumlah seperempat penduduk bumi. Hal itu menunjukkan bahwa sarana kematian itu beroperasi bukan hanya pada satu daerah tertentu, tetapi mencapai berbagai wilayah, negera dengan jangkauan yang luas. Artinya sarana pembunuhan manusia ini bisa menyebar begitu cepat, efektif dalam membunuh dan sulit untuk dihentikan. Karena itu ketika ada wabah melanda manusia dan penyebarannya cepat serta dengan jangkauan yang luas, dapat menyebar ke berbagai negara, tentu hal itu mendorong manusia berpikir apakah ada hubungan nubuatan dalam Alkitab dengan wabah itu.

Hal yang sama sedang terjadi dengan covid 19 ini. Wabah ini begitu cepat menyebar dan hanya dalam hitungan bulan telah mencapai hampir semua negara di dunia. Dan yang menjadi perhatian adalah jumlah orang yang tertular terus bertambah dari bulan ke bulan, bahkan setiap dari selalu ada saja pasien baru yang terinfeksi covid 19. Memang dimasa lalu pernah ada berbagai wabah yang melanda dunia ini, dengan jumlah kematian yang tidak sedikit.

Salah satu yang wabah yang telah menjangkiti manusia dan membunuh manusia dalam jumlah yang besar pada abad yang lampau adalah flu Spanyol. Pandemi influenza ini terjadi pada tahun 1918 yang disebabkan oleh virus H1N1 yang ditengarai berasal dari unggas. Meskipun tidak ada kesepakatan tentang sumber virus ini, yang pasti virus ini telah menyebar ke seluruh dunia selama tahun 1918-1919. Diperkirakan sekitar 500 juta orang atau sepertiga populasi dunia terinfeksi virus ini. Dengan jumlah kematian diperkirakan sekitar 50 juta di seluruh dunia. Kematian paling tinggi terjadi pada orang yang berusia kurang dari 5 tahun, 20-40 tahun, dan 65 tahun ke atas. ${ }^{17}$ Tentu flu Spanyol ini merupakan wabah yang menggemparkan kala itu, karena jumlah kematian yang tidak sedikit, apalagi jumlah penduduk dunia waktu itu belum seperti sekarang ini.

Dan ketika sekarang dunia menghadapi covid 19, yang telah menyebar secara efektif ke berbagai negara, manusia diingatkan lagi bahwa wabah besar sedang melanda dunia. Dalam keadaan demikian, manusia kembali berpikir apakah wabah ini merupakan tandatanda zaman, apakah wabah ini telah dinubuatkan dalam Alkitab. Pandemi covid 19 merupakan wabah yang perlu untuk diamati, tidak hanya dari perspektif ilmu kedokteran tetapi juga dalam hubungan dengan theologi, berkenaan dengan rencana Allah atas akhir dunia ini, seperti yang dinubuatkan dalam Wahyu 6:8.

\section{Covid 19 dan Penyebarannya}

Covid-19 pada dasarnya adalah penyakit pernapasan yang dimulai di paru-paru, menyebabkan gejala mirip pneumonia, tetapi juga dapat menyebabkan badai di seluruh tubuh. ${ }^{18}$ Pada bagian lain virus corona ini merupakan keluarga virus yang awalnya dapat menyebabkan penyakit seperti flu biasa, kemudian dapat menyebabkan

sindrom pernapasan akut parah (SARS), dan sindrom pernapasan Timur Tengah (MERS). Pada 2019, virus korona baru teridentifikasi sebagai penyebab wabah penyakit yang berasal dari China. Virus tersebut sekarang dikenal sebagai sindrom pernafasan akut

\footnotetext{
${ }^{17}$ https://www.cdc.gov/flu/pandemic-resources/1918-commemoration/1918-pandemic-history.htm, Mei 2020

${ }_{18}$ https://www.nationalgeographic.com/science/health-and-human-body/human-diseases/coronavirus/, Mei 2020
} 
parah coronavirus 2 (SARS-CoV-2). Penyakit yang ditimbulkannya disebut penyakit corona virus 2019 (COVID-19). Pada Maret 2020, Organisasi Kesehatan Dunia (WHO) menyatakan wabah COVID-19 sebagai pandemi. ${ }^{19}$ Hal itu sesuai dengan kenyataan yang menunjukkan bahwa virus corona ini telah menjangkiti banyak orang di berbagai negara. Dan dampak virus ini begitu meluas, sehingga sulit diprediksi kapan wabah ini akan berhenti. Dengan demikian tepat sekali jika covid 19 ini disebut sebagai pandemik global, karena telah menyebar dan menjangkiti banyak orang di berbagai negara di dunia.

\section{Cara Virus Menyebar}

Seperti penyakit pernapasan lainnya, covid 19 terutama menyebar melalui tetesan kecil — air liur atau lendir — yang dikeluarkan orang yang terinfeksi saat mereka batuk, bersin, atau berbicara. Ada juga bukti bahwa virus covid 19 dapat bertahan di permukaan - terutama plastik atau logam - hingga 3 hari. ${ }^{20}$ Karena itu untuk menghindari tertular dari covid 19, diupayakan dengan mencuci tangan dengan sabun, menggunakan bahan pembersih dari alkohol dan menjaga jarak dari orang lain. Berikut penjelasan secara detail penyebaran virus corona ini.

\section{Dari orang ke orang}

Seseorang dapat menjadi sakit jika terinfeksi SARS-CoV2, virus corona baru yang menyebabkan covid 19. Dalam tubuh manusia ada pembelaan diri terhadap virus dengan berbagai cara. Garis pertahanan pertama adalah kulit. Kulit membentuk semacam dinding di sekitar tubuh yang tidak bisa ditembus oleh banyak patogen. Selain itu, ada banyak garis pertahanan lain yang harus dilewati patogen sebelum orang itu menjadi sakit, yaitu sistem kekebalan tubuh. Karena alasan itu, satu partikel virus jarang dapat membuat seseorang sakit. Seseorang biasanya jatuh sakit karena bersentuhan dengan banyak partikel virus dalam jangka waktu tertentu.

Seseorang yang sakit oleh virus corona menghasilkan jutaan salinan virus di dalam tubuhnya. Virus ini terutama ditemukan di paru-paru, tetapi juga di bagian tubuh 'lembab' lainnya, seperti tenggorokan atau rongga hidung. Saat bersin atau batuk, virus akan terdorong keluar udara: banyak tetesan juga keluar dari paru-paru, tenggorokan, atau rongga hidung. Dalam keadaan ini virus corona akan menyebar melalui tetesantetesan ini. Jika orang lain menghirup tetesan-tetesan itu, atau memasukkannya ke mulut, hidung atau mata mereka, misalnya melalui tangan mereka, maka mereka bisa terinfeksi virus corona.

\section{Tetesan besar atau kecil}

Meskipun virus corona masih merupakan virus yang cukup baru, dan ada banyak hal yang belum diketahui tentang virus ini, tetapi pola penyebarannya sudah dapat diketahui. Bahwa virus ini menyebar dari satu orang ke orang lain sebagian besar melalui tetesan yang agak lebih besar. Umumnya tetesan yang lebih besar tidak bergerak sejauh 1 meter, jarang mencapai 1,5 meter.

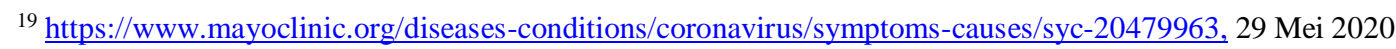

${ }^{20} \mathrm{https} / / /$ www.gavi.org/vaccineswork/what-is-covid-19-and-how-does-it-spread, 28 Mei 2020
} 
Dalam keadaan normal, akan tampak bahwa ada risiko minimal penyebaran virus corona melalui tetesan kecil yang tetap menggantung di udara dikenal sebagai aerosol, walaupun masalah ini masih menjadi perdebatan. Tampaknya tetesan aerosolis kecil, atau dosis virus dalam tetesan yang lebih kecil biasanya tidak cukup untuk menginfeksi seseorang, kecuali dalam konsentrasi yang sangat tinggi, seperti ketika ventilasi pasien covid 19 dalam perawatan intensif. Karena itu tetasan yang lebih besar merupakan pembawa resiko penyebaran virus corona dalam tingkat yang tinggi, yaitu ketika mereka yang mengidap virus corona bersin atau batuk. ${ }^{21}$ Penyebaran Virus Corona Di Indonesia dan Dunia

Pandemi covid 19 di Indonesia adalah bagian dari pandemik penyakit virus corona di seluruh dunia, yang telah menyebar hampir di semua negara di penjuru dunia ini. Penyebaran virus corona di Indonesia terkonfirmasi dimulai pada tgl 2 Maret 2020, setelah seorang instruktur tari dan ibunya dinyatakan positif terjangkit virus corona. Kedua orang ini tertular dari seorang warga negara Jepang.

Kemudian pada tgl 9 April 2020, pandemi ini telah menyebar ke semua provinsi di Indonesia. Selanjutnya pada tgl 23 Mei 2020, setengah dari provinsi itu dinyatakan telah memiliki lebih dari 1.000 kasus. Jawa Timur, Jakarta, dan Sulawesi Selatan adalah provinsi yang paling banyak mengalami pandemik virus corona ini. Dalam hal jumlah kematian, Indonesia berada di peringkat kelima di Asia. Namun, jika dilakukan tinjauan ulang terhadap data yang ada bahwa ada indikasi jumlah kematian mungkin jauh lebih tinggi daripada yang dilaporkan sebab ada orang yang meninggal dengan gejala covid 19 tetapi belum sempat dikonfirmasi atau diuji, sehingga tidak terhitung sebagai angka kematian resmi oleh karena covid 19.

Untuk mengatasi pandemik virus corona ini pemerintaha melakukan langkahlangkah taktis, seperti diberlakukannya PSBB (Pembatasan Sosial Berskala Besar). Beberapa daerah telah menerapkan pembatasa sosial ini, dan hasilnya adanya penurunan angka dalam jumlah kasus, tetapi dibeberapa daerah cenderung meningkat. ${ }^{22}$

Menurut informasi dari gugus tugas penanganan covid 19 bahwa jumlah orang yang positif covid 19 di Indonesia cenderung terus meningkat. Hari Selasa, tgl 26 Mei 2020 jumlah orang yang positif covid 19 bertambah 415 orang, sehingga total orang yang dinyatakan positif covid 19 menjadi 23.165 orang. Hal itu disampaikan secara langsung oleh juru bicara pemerintah untuk penanganan covid $19 .{ }^{23}$

Pada bagian lain, bahwa di berbagai negara di dunia, terdapat sebanyak

5.326.230 orang positif covid 19. Sedangkan menurut Worldometers pada hari Sabtu, tgl 23 Mei 2020, negara yang paling menderita oleh covid 19 ini adalah Amerika Serikat, dengan jumlah total yang positif covid 19 sebanyak 1.645 .353 orang, dan jumlah kematian sebanyak 97.655 orang. Kemudian Rusia adalah negara kedua yang terbanyak yang mengalami dampak covid 19, sebanyak 335.882 orang positif. Selanjutnya Brasil sebanyak 332.382 orang, menyusul Spanyol sebanyak 281.904 orang, di negara Inggris sebanyak 254.195 orang, di Italia sebanyak 228.658 orang, di negara Perancis sebanyak 182.219 orang. Dengan demikian jumlah total orang yang terinfeksi covid 19 di seluruh dunia sebanyak 5.326.230 orang, dengan angka kematian 340.383 orang. Dan virus corona ini telah melanda sejumlah negara diperkirakan sebanyak 213 negara di seluruh dunia. $^{24}$ 


\section{Hubungan Nubuatan Dalam Wahyu 6:8 Dengan Covid 19}

Dari penjelasan sebelumnya dapat dikatakan bahwa maut dan hades membunuh manusia secara global dengan pedang, kelaparan, wabah atau penyakit dan binatang buas. Pedang dan kelaparan merupakan dua alat pembunuh manusia yang berlangsung di beberapa tempat seperti di Afrika, Asia Tengah. Lalu muncul pemikiran apakah wabah covid 19 merupakan wabah atau penyakit yang dimaksudkan oleh Wahyu 6:8 ini ?

Jika memperhatikan penyebaran virus corona sejauh ini, nampaknya belumlah dapat disebutkan sebagai wabah yang disebutkan dalam Wahyu 6:8. Karena skala kematian yang disebabkan oleh virus corona sejauh ini belum bisa disebut sebagai tingkat kematian yang bisa mencapai hampir seperempat penduduk bumi. Karena sekarang ini seperempat dari penduduk bumi hampir 1,9 milliar. Sementara angka kematian yang disebabkan oleh viris corona dalam berbagai negara sejauh ini baru dalam kisaran 340.383 jiwa.

Dengan demikian belumlah dapat disebutkan bahwa virus corona adalah nubuatan yang disebutkan dalam Wahyu 6:8. Artinya kematian yang diakibatkan covid 19 masih sangat jauh dari jumlah angka seperempat penduduk dunia. Kalau pun ditambahkan dengan jumlah orang yang mati akibat peperangan dan kelaparan di berbagai belahan dunia seperti Afrika dan Asia Tengah, sejauh ini belum menunjukkan angka yang signifikan yang mencapai jumlah seperempat penduduk bumi. Karena itu sejauh yang dapat diamati bahwa wabah yang disebutkan dalam Wahyu 6:8 tidak menunjuk kepada covid 19. Bahwa sejauh ini (data bulan Mei 2020) tidak dapat dikatakan bahwa nubuatan dalam Wahyu 6:8 mempunyai relasi dengan covid 19, seperti yang sudah dijelaskan sebelumnya.

Pada bagian lain, jika penyebaran virus corona masih terus berlangsung dan berkembang dalam jangka waktu yang lama, seperti diprediksi oleh para ahli, dengan jumlah korban yang terus meningkat, maka barangkali mau tidak mau virus ini bisa juga dihubungkan dengan Wahyu 6:8, dengan syarat jumlah korban terus bertambah-tambah. Sekarang penyebaran covid 19 ini begitu cepat dan mudah menular dari seorang kepada orang lain, maka kemungkinan jumlah korban yang meninggal bisa terus bertambah.

Berbagai upaya telah dilakukan oleh berbagai negara untuk rakyatnya agar penyebaran covid 19 ini bisa ditekan. Dengan menganjurkan masyarakat sadar kesehatan, sadar protokol kesehatan saat beraktifitas di luar rumah. Hal yang sama dilakukan pemerintah Indonesia. Dengan berbagai cara pemerintah menjelaskan tentang perlunya kesadaran bersama untuk menjaga kesehatan, dengan memperhatikan protokol kesehatan dengan menjaga jarak, rajin cuci tangan dan selalu memakai masker, agar terhindar dari covid 19. Tetapi kenyataannya tingkat kesadaran masyarakat sering masih belum seperti yang diharapkan. Masih banyak yang kurang perduli kesehatan, dengan mengabaikan protokol kesehatan seperti yang dianjurkan pemerintah. Jika keadaan ini tidak berobah, maka bukan tidak mungkin Indonesia bisa menjadi negara dengan jumlah penderita covid 19 terbanyak di seluruh dunia. Apalagi jika hunian padat diberbagai daerah kurang memperhatikan protokol kesekatan, bisa mengakibatkan penyebaran virus ini sulit untuk dikendalikan dan diatasi. Karena itu jumlah korban oleh virus corona ini bisa saja akan terus meningkat pada jumlah yang sulit diprediksi.

Jika penyebaran virus corona ini berlangsung lama dan jumlah penderita serta yang meninggal terus meningkat, maka bisa saja covid 19 dapat dihubungkan dengan Wahyu 6:8. Dan sejauh ini wabah yang ditimbulkan virus ini belum menunjukkan tanda-tanda akan berhenti, malah dalam konteks Indonesia, wabah ini sedang mengganas, dengan bertambahnya terus jumlah orang yang tertular. Jika penyebaran covid 19 akan masih terus berlangsung lama dengan jumlah korban masih terus bertambah, bukan tidak 
mungkin bahwa nubuatan dari Wahyu 6:8 memiliki hubungan dengan covid 19. Karena itu perkembangan dan penyebaran covid 19 masih perlu terus diamati, untuk memastikan ada tidaknya hubungan antara nubuatan dalam Wahyu 6:8 dengan covid 19.

\section{Kesimpulan}

Wahyu 6:8 menunjukkan bahwa akan ada suatu masa malapetaka yang dahsyat yang menimpa manusia, yang ditimbulkan oleh maut dan hades, dengan jumlah kematian yang sangat. Bahwa kedua kekuatan kegelapan itu akan membunuh manusia sebanyak seperempat penduduk bumi. Suatu angka yang sangat fantastis, mengingat jumlah penduduk dunia dewasa ini sekitar 7.8 miliar. Mungkin angka kematian manusia terbesar sepanjang sejarah.

Sekarang ini dunia sedang sakit karena pandemik covid 19 yang telah menewaskan sejumlah besar manusia diberbagai negara. Ketika pandemik ini muncul, ada orang mulai mencoba menghubungkan nubuatan dalam Wahyu 6:8 dengan covid 19 ini. Apakah ada hubungan diantara ke duanya, apakah nubuatan dalam Wahyu 6:8 menunjuk kepada covid 19.

Dengan memperhatikan wabah yang sedang melanda dunia oleh covid 19 ini, membuat banyak orang kaget dan stres karena penyebaran yang begitu mudah dan telah menyebar dengan cepat ke berbagai negara. Jumlah orang tertular pun terus menunjukkan pertambahan dari minggu ke minggu, dengan angka kematian yang juga tidak sedikit. Tetapi jika diperhatikan Wahyu 6:8, yang menegaskan bahwa kematian oleh pedang, kelaparan, wabah mencapai seperempat penduduk dunia, nampaknya belum menunjukkan ada indikasi bahwa covid 19 ini yang dimaksudkan oleh nubuatan dalam Wahyu 6:8. karena jumlah kematian yang disebabkan oleh dengan covid 19, masih terlalu jauh dengan angka kematian yang dinyatakan oleh Wahyu 6:8. Karena itu sejauh ini belum dapat dikatakan bahwa covid 19 adalah merupakan nubuatan yang dinyatakan dalam Wahyu 6:8.

Tetapi hubungan antara nubuatan dalam Wahyu 6:8 dengan covid 19 masih terus terbuka untuk didiskusikan. Dengan memperhatikan bahwa pandemik covid 19 belum menunjukkan tanda-tanda akan usai. Sejauh ini covid 19 masih terus menjadi problem besar bagi banyak negera, termasuk Indonesia. Jumlah orang yang terinfeksi masih menunjukkan angka yang cenderung terus meningkat. Jika vaksin covid 19 ini belum ditemukan dalam beberapa tahun ke depan, maka bukan tidak mungkin angka kematian yang diakibatkan covid 19 akan terus meningkat sampai angka yang sangat besar. Kalau hal itu yang terjadi maka bukan tidak mungkin ada orang berpikir bahwa nubuatan Wahyu 6:8 menunjuk kepada covid 19. Kalau hal itu betul-betul terjadi dengan adanya peningkatan yang terus menerus dari jumlah kematian yang diakibatkan covid 19 ini, maka mungkin saja nubuatan dalam Wahyu 6:8 menunjuk kepada covid 19 . Tetapi semua itu berpulang kepada besarnya dampak penyebaran dan kematian yang diakibatkan oleh covid 19 ini. Karena itu perlu waktu untuk menunggu dan memperhatikan apa yang akan terjadi dengan perkembangan pandemik covid 19 ini. Dengan demikian untuk membuktikan adanya hubungan antara nubuatan yang terdapat dalam Wahyu 6:8 dengan covid 19, perlu waktu dan pengamatan terhadap penyebaran dan dampak yang diakibatkan oleh covid 19. 
Daftar Pustaka

Beale, G.K.

2015 Revelation, A Shorther Commentary, Grand Rapid Michigan: Wm B. Eerdmans Publishing

1999 The Book of Revelation : A Commentary on the Greek Text. Grand Rapids, Mich.; Carlisle, Cumbria : W.B. Eerdmans; Paternoster Press

Duval, J. Scott ,

2014 Revelation, Teach The Tex t, Commentary Series, Grand Rapid Michigan, Baker Publishing Group

Kistemaker, Simon J.;Hendriksen, William,

2001 New Testament Commentary: Exposition of the Book of Revelation.

Grand Rapids: Baker Book House

Oborne, Grant R. .

2016 Revelation, Verse by Verse Osborne New Testament Commentaries, Bellingham, Lexham Press.

Pandensolang, Welly,

2010 Gramatika dan Sintaksis Bahasa Yunani Perjanjian Baru; Jakarta, YAI Press

Thomas, Robert L. .

1995 Revelation, An Exegetical Commentary, Chicago; Moody Press

${ }^{10}$ http://www.intothyword.org/apps/articles/web/articleid/33364/columnid/3803/default.asp, diakses tgl 17 Mei 2020

${ }^{11} \mathrm{http} / / /$ biblicalelearning.org/wp-content/uploads/2019/09/Chapter_22_Infinitives.pdf, 13 Mei 2020

${ }^{12}$ G. K. Beale. Revelation, A Shorther Commentary, Grand Rapid Michigan: Wm B. Eerdmans Publishing, 2015, 13 
